\title{
The Relationship Between Political Skill And Employee Voice Behavior: From An Impression Management Perspective
}

\author{
Xian Xue, Xi'an Jiaotong University \& \\ The Key Lab of the Ministry of Education for Process Control \& Efficiency Engineering, China \\ He Yi Song, Xi' an Jiaotong University \& \\ The Key Lab of the Ministry of Education for Process Control \& Efficiency Engineering, China \\ Yu Jie Tang, Xi'an Jiaotong University \& \\ The Key Lab of the Ministry of Education for Process Control \& Efficiency Engineering,China
}

\begin{abstract}
This research focused on the self-serving motivation of voice behavior from an impression management perspective, different from the previous studies on the altruistic motivation. The purpose of this study was to construct a multilevel theoretical model that proposed how political skill operates to exercise effects on employee voice behavior in the context of organizational politics climate from an impression management perspective. We hypothesized the positive relationship between political skill and employee voice behavior, and the mediating role of impression-management motives, and then examined the cross-level effects of organizational politics climate on the individual-level employee voice phenomenon. An evaluation of research limitations, suggestions for future research, contributions to the literature and practical implications were discussed finally.
\end{abstract}

Keywords: Employee Voice; Political Skill; Impression-Management Motives; Organizational Politics Climate

\section{INTRODUCTION}

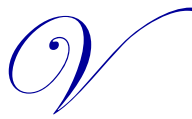

oice is ubiquitous in organizations. In the organizational sciences, employee voice is conceptualized as a behavior rather than as an attitude or a perception (Ng \& Feldman, 2012). LePine and Van Dyne (1998) defined voice as an extra-role behavior, that is, expressing change-oriented ideas, opinions, and suggestions for improving the situation at work. Voice is presumed to enhance the efficiency and effectiveness of task processes, address problems in work systems, help identify untapped markets, and lead to many other positive learning and performance outcomes (Dutton \& Ashford, 1993; Morrison \& Milliken, 2000). The wisdom is received generally that voice is good and its absence is problematic (Detert, Burris, Harrison, \& Martin, 2013). Accordingly, how to motivate employees to exercise voice initiatively has been an important question for practitioners and organizational scholars.

Most research on voice behavior has been grounded in social exchange theory (Blau, 1964) and the norm for reciprocity in particular (Cropanzano \& Mitchell, 2005). These studies suggest employees engage in voice behavior resulting from other-serving motives. This perspective assumes that employees mostly use voice as a means of keeping the social exchange relationship with organizations based on the norm of reciprocity. However, prior literature has largely ignored the possibility that employees use voice to regulate personal resource as well $(\mathrm{Ng}$ \& Feldman, 2012). Bolino (1999) studied the relevance of various acts of impression management in relation to citizenship behaviors and believed that such citizenship behaviors might be self-serving and impression enhancing. That is, people who engage in citizenship are likely to be favorably perceived by others. Van Dyne, Ang, and Botero (2003) also emphasized that voice can be either other-directed or self-directed. Later Fuller and his colleagues (2007) demonstrated that engaging in voice behavior can be viewed as a tactic of impression management. 
Employees who speak up might want to shape their positive images and enhance their reputations as helpful, capable contributors, so they are actually self-serving, not for the sake of organizations. Besides, Roberts (2005) demonstrated that the impression management has broad applicability and is useful in helping to explain many organizational functions and that future research should place greater emphasis on developing broader and more encompassing theories of how image concerns may arise and how these concerns shape behaviors across contexts. According to these studies, we propose the impression management theory will prove useful in understanding what motivates voice behaviors. The purpose of the current study is to adopt the perspective of impression management to investigate employee voice phenomenon in Chinese organizations.

The most prominent feature of the Chinese culture is its emphasis on harmonious interpersonal relationships or guanxi orientation (Hwang, 1987), so that impression management tactics that people usually use to protect their "face" or enhance their images as well as improve human relations are essential in China. Therefore, in the Chinese context, voice can be seen as a tactic to enhance impression. Furthermore, in Chinese organizations with the features of high power distance and salient political environment, employees need to possess political skill as the requisite competency to successfully practice politics in the workplace. Political skill is a relatively new construct which represents the ability of individuals in influence situations (Harris, Kacmar, Zivnska, \& Shaw, 2007; Ferris, et al., 2005). Individuals with political skill at work can accurately adjust their behavior to different and changing situational demands and appear to be sincere and trustworthy and therefore are perceived to possess no ulterior motives (Ferris, et al., 2007). As such, it may be interesting to explore how and why politically skilled individuals exhibit voice behavior towards peers or supervisors at the workplace in China.

Based on the above background, this study aims to build a bridge between the research on political skill and voice behavior by exploring the effects of political skill on employee voice from the perspective of impression management. Specifically, this study has three objectives: (a) to examine how political skill operates to exercise effects on employee voice; (b) to explore the influence mechanism of political skill on employee voice and to analyze the possible reason why employees engage in voice behavior; (c) to investigate the cross-level effects and the moderating effects of organizational politics climate. Overall, we will construct a theoretical model that proposes how political skill operates to exercise effects on employee voice behavior from the perspective of impression management. The theoretical model is expected to explore the extent to which worker personality (i.e., political skill) interacts with a contextual feature of the workplace (i.e., organizational politics climate) to predict when and how some people engage in voice behavior.

\section{LITERATURE REVIEW AND THEORETICAL BACKGROUND}

\section{Employee Voice}

Since Hirschman proposed the concept of voice, how to effectively encourage employees to speak up or voice has become a hot topic in the field of organization management (Burris, Detert, \& Chiaburu, 2008). Van Dyne and LePine (1998) defined voice as non-required behavior that emphasizes expression of change-oriented comments with a motive to improve rather than merely criticize the situation. Until now, scholars' focus has been mainly on predicting voice. Antecedents of employee voice that have been revealed mainly includes two categories: one is the individual characteristics (e.g., personality, cognitive style and demographic characteristics) and psychological perception (e.g., psychological safety, a sense of fairness), whose basic assumption is that individual differences in characteristics or attitudes determine some people prefer to voice than others; the other is situational factors whose basic assumption is that even the most high satisfactory and initiative employees may play it by ear or read the wind, and determine whether it is worthwhile and safe to engage in voice depending on the specific situation (Milliken, Morrison, \& Hewlin, 2003).

There have been some scholars who studied employee voice from different perspectives. For instance, Fuller et al. (2007) from the viewpoint of impression management, believe that engaging in voice may be viewed as an image enhancement tactic and self-serving, while refraining from engaging in voice behavior may be due to fear of image damage. Those who are good at observing and understanding organizational context will hunt for an appropriate time to engage in voice towards supervisors or coworkers, in order to make positive impressions on others at work and hope these people help their future career development (Bolino, Kacmar, Turnley, \& Gilstrap, 
2008). Bolino (1999) once described such individuals as"good actions." Except this above viewpoint, however, the common view made by the most other scholars is that voice stems from an individual's desire to help the organization or other people, and Bolino (1999) described such individuals as"good soldiers"or "good citizens".

Current research on the construct structure of voice yet has not formed a consistent view because scholars divided voice into different dimensions from their own point of views. For example, Van Dyne et al. (2003) differentiated three types of voice (acquiescent voice, defensive voice, prosocial voice) based on employee motives; Liu, Zhu and Yang (2010) believed that the employee who engage in voice is target-sensitive, so voice can be divided into two dimensions - voice toward peers and voice toward the supervisor; Liang and Farh (2012) proposed a two-dimensional voice model — promotive voice behavior and prohibitive voice behavior.

Since the target audiences of individual impression management are his or her colleagues and supervisors, and according to the purpose of this study, we will adopt the classification by Liu et al. (2010), dividing voice into voice toward peers and voice toward the supervisor. This article will explore the formation mechanism of employee voice by the combination of individual traits, psychological motivation, organizational context and the interaction of individual and context.

\section{Political Skill}

Political skill is a relatively new construct that was introduced more than two decades ago as a necessary competency to possess to be effective in organizations (Ferris et al., 2007). Pfeffer (1981) was one of the first to use the term political skill in the scholarly literature and suggested that political skill is needed for employees to be successful in an organization. Mintzberg $(1983,1985)$ viewed organizations as political arenas, and suggested that survival and effectiveness in such contexts required political skill. Subsequently, Ferris et al. (2007, p, 291) defined political skill as "the ability to effectively understand others at work, and to use such knowledge to influence others to act in ways that enhance one's personal and/or organizational objectives". They also indicated four critical dimensions of political skill: social astuteness, interpersonal influence, networking ability, and apparent sincerity. The social astuteness dimension refers to that individuals understand social interactions well and interpret their behavior and others' behavior accurately. Pfeffer (1992) referred to this characteristic as being sensitive to others, and he demonstrated that the ability to identify with others is critical to obtaining one's goals. The dimension of interpersonal influence allows individuals to adapt their behavior to different situations and receive the desired responses from others. The interpersonal influence dimension captures what Pfeffer (1992) referred to as "flexibility," which involves adapting individuals' behavior to different targets of influence in different contextual settings to obtain things for oneself (Ferris et al., 2007). Individuals with political skill are adept at identifying and developing diverse networks and contacts of people (Ferris et al., 2007). Individuals who are high in networking ability can both create and take advantage of opportunities (Pfeffer, 1992). The dimension of apparent sincerity connotes that individuals are or appear to be, honest and forthright. Subsequent conceptual and empirical development has lent support to the robustness of the structure of political skill (Ferris et al., 2007).

Organizations particularly in China can be seen as game arenas of power, which link with environmental uncertainty and resource control, within it individuals are faced with limited resources to obtain benefits and selfgoals through different ways. Political skill is characterized as being essential for effectiveness at work and in successfully dealing with the political realities of organizations. Thus, one of our objectives is to find out what behavioral tendencies individuals possessing political skill may have, so we will examine the predicting role of political skill on employee voice.

\section{Impression-Management Motives}

Goffman (1959) first conceptualized the phenomenon of impression management within his dramaturgical model of social life. According to Goffman, persons in social interaction function as "actors" whose "performances" depend upon characteristics of both the situations and the audiences at hand. Through this interaction with and influence upon both situations and audiences (i.e., the environment), actors can better position themselves to achieve their desired ends. Thus, impression management is purposive, goal-directed behavior. 
The phenomenon of impression management (IM) has been alternatively defined as "the conscious or unconscious attempt to control images that are projected in real or imaged social interactions" (Schlenker, 1980, p. 6), "any behavior by a person that has the purpose of controlling or manipulating the attributions and impressions formed of that person by others" (Tedeschi \& Riess, 1981, p. 3), and "an attempt by one person (actor) to affect the perceptions of her or him by another person (target)" (Schneider, 1981, p. 25). Based on the review of impression management by Leary and Kowalski (1990), there are three main factors determining the motivation to manage impressions: (1) the goal relevance of impressions, (2) the value of image enhancement, and (3) the discrepancy between current and desired images.

Impression-management theorists suggest that a primary human motive, both inside and outside of organizations, is to be viewed positively by others and to avoid being viewed negatively (Rosenfeld, Giacalone, \& Riordan, 1995). IM occurs because an actor has a goal of creating and maintaining a specific identity. This goal is achieved by strategically exhibiting behaviors, both verbal and nonverbal, that will make a target to view the actor as desired.

Recent theories and research have suggested that a significant portion of individual behavior in organizations is motivated by impression management concerns, that is, by the desire to be perceived by others in certain ways. IM has been studied in a variety of areas such as leader-member exchange (Wayne \& Ferris, 1990), job interviews (Kacmar, Delery, \& Ferris, 1992) and performance appraisal (Wayne \& Kacmar, 1991). In the Chinese context, impression management has been documented as a common phenomenon in the workplace. As such, we will apply IM theory and concept, and seek to better understand employee voice phenomena in Chinese organizations.

\section{Organizational Politics Climate}

Studies have long argued that politics is an epidemic phenomenon in organizations (Mintzberg, 1983; Pfeffer, 1981, 1992). Politics in organizations is simply a fact of life. Organizational politics (OP) is perceived as self-serving behavior by employees to achieve self-interests and benefits at the expense of others and sometimes contrary to the interests of the entire organization or work unit.

Lewin (1936) suggested a very important notion that people respond on the basis of their perceptions of reality, not reality itself. Later on, Porter (1976) argued that perceptions are important to study and to understand, even if they are misperceptions of actual events. Likewise, politics in organizations should be understood in terms of what people think of it rather than what it actually represents. Studies thus proposed that perceptions of organizational politics or justice and fairness reflect a political climate in the workplace. Perceptions of organizational politics (POP) are the factors that contribute to employees perceiving a work environment as political in nature and the consequences of forming such perceptions on individual attitudes and behaviors (Ferris \& Kacmar, 1992).

The importance of organizational politics (OP) lies in its potential consequences and effect on work outcomes. A political organizational climate may suppress unfair and unjust activities that are easily observed by employees. When an employee feels deprived and unfairly treated because of political considerations, he or she will be inclined to react initially by reducing voluntary obligation and attachment to the organization (Ferris \& Kacmar, 1992). Employees with high perceptions of organizational politics will tend to show lower levels of job satisfaction and organizational commitment than other employees, and may put less effort in their work, or show no creativity and initiative even though they are capable of it.

In Chinese context, the use of political tactics in organizations is widespread. Everyone is dominated under the influence of the pattern of different sequences which is considered the distinctive feature of interpersonal relationship (Fei, 1992), so that Chinese organizational members may engage in political behavior to improve the "relation" with leaders and get a position in the leaders' interpersonal circle. That is why virtually every employee in China can recount a political incident in which he or she was directly or indirectly involved. Therefore, we will promote understanding of employees' reactions to organizational politics in China. 


\section{Theoretical Model}

We have a logic thought based on personality and cognitive psychology, which is "personality trait-motivation/cognition--behavior" that becomes the basis of our research model. Personality traits identify individual differences in beliefs, values and skills that appear to generate individual differences in behavior (Ajzen, 1988), and motivation is relevant to goals and goal-oriented behavior (Ajzen, 1985). Psychological literature has argued personality trait may influence cognitions (Langston \& Sykes, 1997) relevant to a motive that leads to an act. The theory of reasoned action (Fishbein, 1979) hypothesized that behavior can best be predicted from a person's intention, or willingness, to perform the behavior. And the theory of planned behavior (TPB) (Ajzen, 1985, 1988, 1991) also proposed that intention is the most proximal, and important, predictor of behavior, and the degree of intention is assumed to capture motivational factors (Ajzen, 1991). Accordingly, we can propose that political skill can generate individual difference in behavior by some motivational factors.

Based on our logic thought and the person-situation interactionist, we construct a theoretical model, as shown in Figure 1, which proposes how political skill operates to exercise effects on employee voice behavior from the perspective of impression management. Specifically, we put forward five propositions to explore the extent to which worker personality (i.e., political skill) interacts with a contextual feature of the workplace (i.e., organizational politics climate) to predict when and how some employees engage in voice behavior. As shown in Figure 1, the proposed model examines the main relationship of political skill and employee voice behavior and the mediating role of impression-management motives at the individual level. This model also examines the effects of organizational politics climate on the individual level relationships. Organizational politics climate at the organizational level has not only the direct cross-level effect on employee voice, but also the moderating effects on the main relationship and on the mediation mechanism at the individual level.

Figure 1. The proposed theoretical relationships

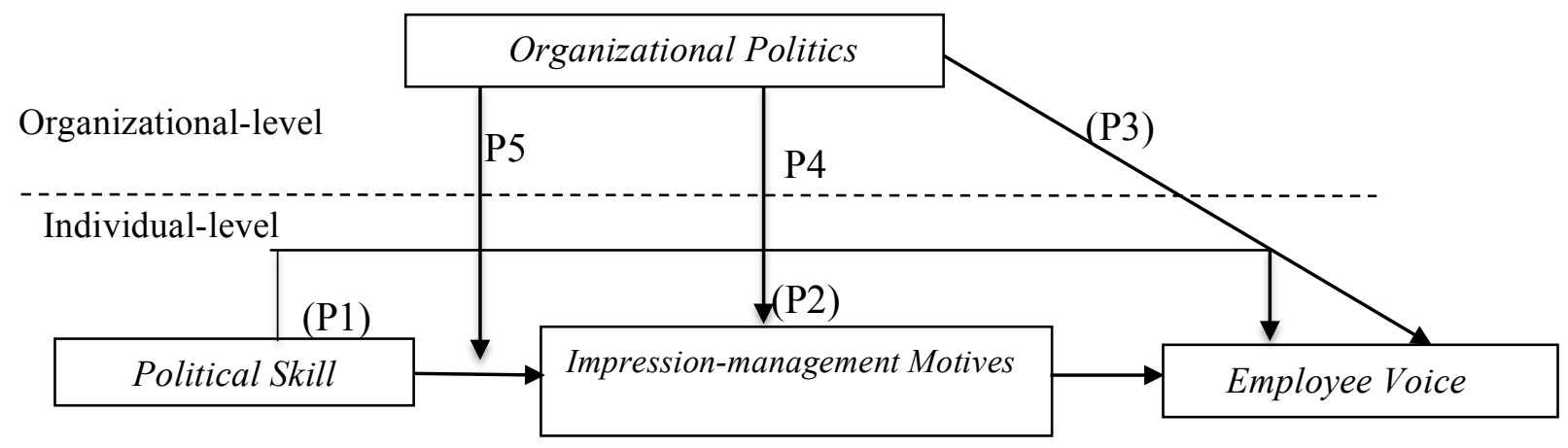

PROPOSITIONS

\section{Political Skill And Employee Voice}

Unlike most other citizenship behaviors, voice is challenging rather than affiliative (Van Dyne, Cummings, \& McLean Parks, 1995). As such, it can be a riskier behavior for the speaker (Detert et al., 2013). Employees who intend to be helpful by speaking up may instead be viewed as unacceptably challenging authority, rocking the boat, merely complaining and wasting time (e.g., Milliken, Morrison, \& Hewlin, 2003), or showing off and not being a team player (e.g., Ryan \& Oestrich,1991). Thus employees may play it by ear or "read the wind" to determine whether it is safe and not futile to engage in voice behavior in a specific situation. In addition, Van Dyne et al. (2003) suggest that voice can be used to protect the self through a variety of defensive communication (such as proposing ideas that focus on other topics or shifting attention to other people).

During verbal communication, individuals with political skill have the ability to effectively understand others at work, and to use such knowledge to influence others to act in ways that enhance one's personal objectives (Ferris et al., 2005). As such, employee voice is in fact political behavior in organizations from the political 
perspective. People who are willing to voice their opinion seem to be "better" than those who don't. Harris et al. (2007) investigated the effect of an individual's political skill on the impression management effectiveness using a matched sample of 173 supervisor-subordinate dyads and found that individuals who were politically skilled achieved more desirable supervisor ratings than those who were not politically skilled.

Social influence theory (Levy, Collins, \& Nail, 1998) suggests that individual characteristics of influencer may have an important effect on the efficacy of impression management tactics. In this study, employee voice is viewed as a tactic of individual impression management form IM perspective. Social influence theory leads us to postulate that political skill is one key individual variable that will have a strong influence on employee voice. It is reasonable that individuals higher in political skill will be more likely to engage in voice behavior than those low in political skill.

Integrating the ideas introduced above, we offer the first proposition that:

Proposition 1: Political skill will be positively associated with employee voice, that, individuals with high political skill will be more likely to engage in voice behavior than others with low political skill.

\section{The Mediating Roles of Impression-Management Motives}

In terms of impression management, it is likely that individuals higher in political skill will achieve more positive images when managing impressions than those low in political skill (Harris et al., 2007 ). People who engage in voice behavior are likely to be favorably perceived by others (e.g., supervisors, coworkers, and so on) in their organizations, in other words, impression-management motives may stimulate voice behavior.

According to this model shown as Figure 1, employee voice results from an individual's desire to look like a good citizen. We do not mean here that employees engage in voice behavior solely based on impressionmanagement motives; instead, we suggest that impression-management motives may motivate voice behavior in addition to other motives, such as other-serving motives to help another individual at work based on social exchange theory.

Impression management theory suggests that individuals are more motivated to manage impressions when they view such impressions as instrumental in achieving their goals (Leary \& Kowalski, 1990). It is valuable to understand IM motives because they are likely to influence the impact that voice behavior has on organization and work group effectiveness.

Especially in China, impression-management is an important motivational force underlying individual behaviors (Li \& Guo, 1999). Studies have demonstrated that the cultural difference between Chinese and Westerners, in general, is the widely accepted and sanctioned norm of shame and embarrassment (Hwang, Ang, \& Francesco, 2002). In the West, such feelings are proved to be weak traits, while in Chinese societies, these feelings (including the concern for face) are important influence on individual behaviors. (Bond \& Lee, 1981; Earley, 1997; Ho, 1976; Hu, 1944; Redding \& Ng, 1982; Ting-Toomey, 1994). "The notion of face permeates every aspect of interpersonal relationships in Chinese culture because of the culture's overarching relational orientation" (Gao, Ting-Toomey, \& Gudykunst, 1996, p. 289). So, considering the Chinese cultural features, we believe that employees in Chinese organizations particularly those politically skilled have a strong intention to manage their impressions on others for maintaining a positive image or to avoid creating a negative one. We can further infer that employees will engage in voice behavior driven by IM motives.

According to the proceeding discussion, we propose that IM motive has a mediating effect on the relationship between political skill and employee voice.

Proposition 2a: Political skill will be positively associated with IM motive.

Proposition 2b: The relationship between political skill and employee voice is mediated by IM motive. 


\section{The Cross-Level Effects of Organizational Politics Climate}

Virtually every employee in China can recount a political incident in which he or she was directly or indirectly involved. So, examining the political climate of a work unit is crucial for a better understanding of organizations (Kacmar \& Carlson, 1997). Individual perceptions of politics may stem from informal behaviors which are not sanctioned by the organization but which are designed to promote the goals of the individual thereby creating an organizational politics climate (Aryee, Chen, \& Budhwar, 2004). To data research questions such as "what is the effect of perceived politics on organizations and employees", and "is political climate an important factor that improves our understanding of employees" job attitude, behavioral intentions, and behavior at work" have still remained unanswered.

From a social marketplace perspective (Cropanzano, Howes, Grandey, \& Toth, 1997), political environments make for risky environments as there is no way of assuring the safety of one's investment in terms of time and effort. Many organizational researchers have found perception of organizational politics had a negative relationship with job attitudes (e.g., job satisfaction and organizational commitment), a positive relationship with intention to leave the organization (exit), and a stronger positive relationship with negligent behavior (neglect). Yet no studies investigate the relationship between organizational politics climate and voice behavior.

In the following, we will investigate the cross-level effects of organizational-level variable (i.e., organizational politics climate) on the individual-level phenomenon (i.e., employ voice). Specifically, organizational politics climate has the direct effect on employ voice behavior and the moderating effect on the relationship between variables at individual level.

\section{The Direct Effect On Employee Voice}

Organizational politics ought to be conceived of as a subjective evaluation rather than an objective state (Gandz \& Murray, 1980). This is because it is the cognitive evaluation of perceptions of events that influence people's reactions and the outcomes of those reactions (Lewin, 1936). Theoretical arguments suggest that politics often interferes with normal organizational processes (e.g., decision making, rewards and promotion) and damages productivity and performance on individual and organizational levels. Ferris, Russ and Fandt (1989) suggested that at least three potential reactions of employees to organizational politics would be to withdraw from the organization, remain a member of the organization but do not become involved in the politics, and to remain a member of the organization and become involved in the politics. These responses appear similar in nature to Hirschman's (1970) exit, loyalty, and voice, respectively.

Organizational politics climate can be seen one of macro-level organizational characteristics (Schneider, Brief, \& Guzzo, 1996), which has the cross-level effects on the micro-level phenomena. A political organizational climate may suppress unfair and unjust activities that are easily observed by employees (Vigoda, 2000). Ferris and Kacmar (1992) argued the higher the perceptions of politics are in the eyes of an organization member, the lower in that person's eyes is the level of justice, equity, and fairness. Hence employees in high organizational politics climate will be inclined to reduce voluntary obligation and lower dedication.

Based on these discussions, we can infer that organizational political climate may impede the willingness of employees to make suggestions for the organization. And job attitudes may lead to behavioral intentions then to actual behaviors, which is widely accepted in organizational behavior theory. So we propose that organizational political climate will have a negative direct cross-effect on employee voice behavior.

Proposition 3: Organizational politics climate will be negatively associated with employee voice.

\section{The Moderating Effect On the Main Relationship}

The expression of the theoretical model shown as Figure 1 includes a person-situation interactionist model of employee voice. The situational specificity of personality trait-behavior relations calls for better understanding of how personality is expressed as valued work behavior. The conceptual core of this model in the interactionist 
process by which personality traits are expressed, considered here as trait activation. Tett and Guterman (2000) suggest that trait activation is the process by which individuals express their personality traits when presented with trait-relevant situational cues.

Generally, political skill has positive relationship with employee voice in context-free, that is what Proposition 1 assumed. But if embedded in different specific contexts, the relationship between the trait of political skill and the voice behavior will be uncertain. Organizational political climate may offer trait-expression opportunity and exert "press" on individual to behave in trait-related ways. The idea "press" suggests the interaction between traits and situations and the concept of situation trait relevance (Tett \& Guterman, 2000). Pfeffer (1981) argued that there is an optimal match between individuals' political skill and their preference for political environments. Politically skilled individuals have the capacity to adjust their behavior to different and changing situational demands. Possessing a high degree of political skill in the strong organizational politics climate, employees are more likely to engage in voice and view such behavior as instrumental in achieving their goals (e.g., self-expression or promotion, achieving high performance ratings). So, the interaction between political skill and organizational politics climate has an additional effect on employee voice.

According to the person-situation interactionist and trait-activation theory, we assume that organizational politics climate has a moderating effect on the main relationship of political skill and employee voice.

Proposition 4: The relationship between political skill and employee voice will be moderated by organizational politics climate.

\section{The Moderating Effect On the Mediation Mechanism}

In the final section we will look deeper into the nature of work situations and the psychological process mediating trait-behavior linkages. Behavioral interpretation (as expression one trait or another) is context-dependent and demands motivational force.

Most people perceived only the dark side of politics, and indeed there is a dark side, characterized by dysfunctional game playing and destructive opportunism (Ferris \& Kacmar, 1992). However, politics can be positive as well, for individuals and organizations. Pfeffer (1981) has argued that politics are essential to the effective functioning of organizations. Individuals who become proficient at playing politics may realize greater job and career-related rewards (e.g., Wayne \& Ferris, 1990). Organizational politics climate may provide the political skilled individuals the opportunity or occasion to achieve their self-goals (such as creating a desired image in the minds of others).

Social influence theory (Levy, Collins, \& Nail, 1998) suggests that personality trait of the influencer may have an important effect on the efficacy of impression management tactics. In terms of impression management, it is likely that individuals with political skill will engage in some proactive behaviors (e.g., voice behavior) for achieving more positive images that for the sake of the organization (Harris, et al., 2007). We expect to identify situations where the impression-management motive may encourage speaking-up behavior. Organizational politics climate is such a situation that offers trait-relevant situational cues and stimulates impression management motives so that employees will engage in one of organizational behaviors that are considered good and have been advocated by everyone.

According to Figure 1, the mediation mechanism is moderated by organizational politics climate, which is called the moderated medication model (Preacher, Rucker \& Hayes, 2007). Taken from the above, we believe that organizational politics climate could stimulate and enhance the mediating effect of impression-management motive on the relationship of political skill and voice behavior.

Proposition 5a: The interaction between political skill and organizational politics climate will be positively related with IM motives. 
Proposition 5b: The mediating effect of IM motives on the relationship of political skill and employee voice will be moderated by organizational politics climate.

\section{IMPLICATIONS AND DIRECTIONS FOR FUTURE RESEARCH}

In this article we construct a theoretical model that proposed how and when political skill operates to exercise effects on employee voice. This framework introduces the important role of impression management in the speaking-up process. This multilevel model also helps us understand the cross-level effects of organizational politics climate on the individual phenomenon. The theoretical contributions of the present study are fourfold.

Firstly, this study indicates the personality trait of political skill has a positive relationship with employee voice behavior, which future enriches the studies about the antecedents of voice behavior. We have built a bride between the research on political skill and the research on voice behavior.

Second, this study enhances our understanding of impression management that may explain voice behavior. It provides a mediation model for examining the role of image concerns in the context of employee voice phenomenon. We focus on the self-serving motivation of voice behavior from an impression management perspective, different from previous studies which primarily focused on the traditional motives that emphasize either prosocial or social exchange intents. We demonstrate IM is a "viable" theoretical approach for explaining employee behavior in organizations.

Thirdly, this article suggests the double-edged sword of organizational politics climate. The consequences of these political events lead those involved to view organizational politics in their own way. Some, who may have been negatively affected by the political climate, perceive it to be a negative influence to organizations, while others mostly those possessing political skill, who have achieved self-goals by political means, view it as a useful tool in an organization. Also, this article not only investigates the moderating effect of organizational politics climate on the main relationship between political skill and voice behavior, but also on the mediation mechanism, helping us understand the extent to which individual personality (i.e., political skill) interacts with a contextual feature of the workplace (i.e., organizational political climate) to predict when and how employees engage in voice behavior.

Fourthly, this article concerns about the Chinese culture and studies the organizational phenomenon in Chinese context, so it has made a contribution to the literature by generalizing the theory of impression management and organizational politics to non-western contexts and helping western scholars understand Chinese employee voice phenomena.

In addition to the theoretical contributions, there are important practical implications for practicing managers. On the one hand, organizations can provide some training to improve the political skill of employees that are favorable for work efficient. On the other hand, if voice is motivated by impression management motives, it may be less likely to facilitate organization performance. Therefore organizations should be cautious in promoting such behavior. Managers should also realize that an employee who exhibits voice behavior is not necessarily a good staff, but may only be a good actor. The last, organizations should maintain an appropriate and neutral political climate which can play a positive role and eliminate its negative effects.

Finally, since this article mainly focuses on the formation mechanism of voice, future research should consider the consequences such behavior poses for organization functioning and performance. In addition, although impression management can motivate and influence voice behavior, it is important to recognize that impression management is intertwined with other motives and that these different motives may lead to similar behavior (Leary \& Kowalski, 1990). So an important task for future researchers is to study situations where two (or more) motives will lead to different behaviors (such as voice and silence), so that their relative strength can be ascertained. Besides, future research should also collect data to test the hypotheses in this article for supporting the theoretical framework. 


\section{AUTHOR INFORMATION}

Xian Xue is a doctoral candidate in organizational behavior at Xi'an Jiongtong University. Her research interests include employee voice behavior, OCB in Chinese context and leadership processes.

He.Y. Song received his Ph.D. from Chinese Academy of Science and is a professor at Xi'an Jiongtong University. His research interests include organizational behavior and human resource management, and leadership processes.

Yu. J. Tang received her Master's degree form Northwest A\&F University and is a doctoral student major in human resource management at Xi'an Jiongtong University. Her research interests include organizational behavior and human resource management.

\section{ACKNOWLEDGEMENTS}

This paper is sponsored by National Natural Science Foundation of China (Grant number: 71171159; 71032002)

\section{REFERENCES}

Ajzen, I. (1985). From intentions to actions: A theory of planned behavior. In J. Kuhl \& J. Beckmann (Eds.), Actioncontrol: From cognition to behavior. Heidelberg: Springer.

Ajzen, I. (1988). Attitudes, personality, and behavior. Milton Keynes, UK: Open University Press.

Ajzen, I. (1991). The theory of planned behavior. Organizational Behavior and Human Decision Processes, 50:179211.

Aryee, S., Chen, Z. X., \& Budhwar, P. Z. (2004). Exchange fairness and employee performance: An examination of the relationship between organizational politics and procedural justice. Organizational Behavior and Human Decision Processes, 94: 1-14.

Bolino, M. C. (1999). Citizenship and Impression management: Good Soldiers or Good Actors. Academy of Management Review, 24: 82-98.

Bolino, M. C., Kacmar, K. M., Turnley,W. H., \& Gilstrap.J. B. (2008). A Multi-level Review of Impression Management Motives and Behaviors. Journal of Management, 34: 1080-1109.

Bozeman, D. P., \& Kacmar,K. M. (1997). A Cybernetic Model of Impression Management Processes in Organizations. Organizational behavior and human decision processes, 69(1): 9-30.

Bond, M. H., \& Lee, P. W. H. (1981). Face-saving in Chinese culture: A discussion and experimental study of Hong Kong students. In A. Y. C. King \& R. P. L. Lee (Eds.), Social life and development in Hong Kong. Hong Kong: Chinese University Press.

Burris, E. R., Detert, J. R., \& Chiaburu, D. S. (2008). Quitting before leaving: The mediating effects of psychological attachment and detachment on voice. Journal of Applied Psychology, 93: 912-922.

Blau, P. (1964). Exchange and power in social life. New York: John Wiley and Sons.

Cropanzano, R., Howes, J. C., Grandey, A. A., \& Toth, P. (1997). The relationship of organizational politics and support to work behaviors, attitudes, and stress. Journal of Organizational Behavior, 18:159-180.

Cropanzano, R., \& Mitchell, M. S. (2005). Social exchange theory: An interdisciplinary review. Journal of Management, 31:874-900.

Detert, J. R., Burris, E. R., Harrison, D. A., \& Martin, S. R. (2013). Voice Flows to and around Leaders: Understanding When Units Are Helped or Hurt by Employee Voice. Administrative Science Quarterly, 58 (4): 669-701.

Dutton, J. E., \& Ashford, S. J. (1993). Selling issues to top management. Academy of Management Review, 18: 397428.

Earley, P. C. (1997). Face, harmony, and social structure. New York: Oxford University Press.

Ferris, G. R., Russ, G. S., \& Fandt, P. M. (1989). Politics in organizations. In R. A. Giacalone \& P. Rosenfield (Eds.), Impression management in the organization. Hillsdale, NJ: Lawrence Erlbaum.

Ferris, G. R., \& Kacmar, K. M. (1992). Perceptions of organizational politics. Journal of Management, 18: 93-116.

Ferris, G. R., Treadway, D. C., Kolodinsky, R. W., Hochwarter, W. A., Kacmar, C. J., Douglas, C., \& Frink, D. D. (2005). Development and validation of the political skill inventory. Journal of Management, 31: 126-152. 
Ferris, G. R., Treadway, D. C., Perrewe, P. L., Brouer, R. L., Douglas, C., \& Lux, S. (2007). Political Skill in Organizations. Journal of Management, 33(3): 290-320.

Fei, H. T. (1992). From the soil-The foundation of Chinese society. Berkeley, CA: University Free Press.

Fishbein, M. (1979). A theory of reasoned action: Some applications and implications. In H. E. Howe, Jr. (Ed.), Nebraska Symposium on Motivation. Lincoln: University of Nebraska Press.

Fuller, J. B., Barnett, T., Hester, K., Relyea, C., \& Frey, L. (2007). An exploratory examination of voice behavior from an impression management perspective. Journal of Managerial Issues, 19:134-151.

Kacmar, K. M., Delery, J. E., \& Ferris, G. R. (1992). Differential effectiveness of applicant impression management tactics on employment interview decisions. Journal of Applied Social Psychology, 22: 1250-1272.

Gandz, J., \& Murray, V. V. (1980). The experience of workplace politics. Academy of Management Journal, 23:237-251.

Gao, G., Ting-Toomey, S., \& Gudykunst, W. B. (1996). Chinese communication processes. In M. H. Bond (Ed.), The handbook of Chinese psychology. Hong Kong: Oxford University Press.

Goffman, E. (1959). The presentation of self in everyday life. Garden City, NY: Doubleday.

Harris, K. J., Kacmar, K. M., Zivnska, S., \& Shaw, J. D. (2007). The Impact of Political Skill on Impression Management Effectiveness. Journal of Applied Psychology, 92(1): 278-285.

Ho, D. Y. F. (1976). On the concept of face. American Journal of Sociology, 81:867-884.

Hu, H. C. (1944). The Chinese concept of "face." American Anthropologist, 46:45-64.

Hwang, K. (1987). Face and Favor: The Chinese Power Game. American Journal of Sociology, 92(4):944-974.

Hwang, A., Ang, S., \& Francesco, A. M. (2002). The silent Chinese: The influence of face and kiasuism on student feedback-seeking behaviors. Journal of Management Education, 26(1):70-98.

Kacmar, K. M., \& Carlson, D. S. (1997). Further Validation of the Perceptions of Politics Scale (POPS): A Multiple Sample Investigation. Journal of Management, 23(5): 627-658.

Langston, C. A., \& Sykes, W. E. (1997). Beliefs and the big five: cognitive bases of broad individual differences in personality. Journal of Research in Personality, 31:141-165.

Leary, M. R., \& Kowalski, R. M. (1990). Impression management: A literature review and two-component model. Psychological Bulletin, 107: 34-47.

Levy, D. A., Collins, B. E., \& Nail, P. R. (1998). A new model of interpersonal influence characteristics. Journal of Social Behavior and Personality, 13: 715-735.

Lewin, K. (1936). Principles of topological psychology. New York: McGraw-Hill.

Liu, W., Zhu, R., \& Yang, Y. (2010). I warn you because I like you: Voice behavior, employee identifications, and transformational leadership. The Leadership Quarterly, 21: 189-202.

Liang, J., Farh, C.I.C, Farh, J.L. (2012). Psychological antecedents of promotive and prohibitive voice: A two-way examination. Academy of Management Journal, 55(1): 71-73.

Li, Q., \& Guo, D. J. (1999). The self-presentational features of the Chinese and their influential factors. Psychological Science(Chinese journal), 22(6):488-491.

Morrison, E. W., \& Milliken, F. J. (2000). Organizational Silence: A Barrier to Change and Development in a Pluralistic World. Academy of Management Review, 25(4): 706-725.

Milliken, F. J., Morrison, E. W., \& Hewlin, P. F. (2003). An Exploratory Study of Employee Silence: Issues that Employees Don't Communicate Upward and Why. Journal of Management Studies, 40(6): 1453-1476.

Mintzberg, H. (1983). Power in and around organizations. Englewood Cliffs, NJ: Prentice Hall.

Mintzberg, H. (1985). The organization as a political arena. Journal of Management Studies, 22: 133-154.

Ng, T. W. H., \& Feldman, D. C. (2012). Employee voice behavior: A meta-analytic test of the conservation of resources framework. Journal of Organizational Behavior, 33(2): 216-234.

Pfeffer, J. (1981). Power in organizations. Boston: Pitman.

Pfeffer, J. (1992). Managing with power: Politics and influence in organizations. Boston: Harvard Business School Press.

Porter, L.W. (1976). Ogranizations as Political Animals. Presidential address, Division of Industrial organizational Psychology, 84th Annual Meeting of the American Psychological Association, Washington, D.C.

Preacher, K. J., Rucker, D. D., \& Hayes, A. F. (2007). Addressing moderated mediation hypotheses: Theory, methods and prescriptions. Multivariate Behavioral Research, 42(1):185-227.

Redding, S. G., \& Ng, M. (1982). The role of face in the organizational perceptions of Chinese managers. Organization Studies, 3(3):210-219. 
Ryan, K. D., \& Oestreich, D. K. (1991). Driving Fear out of the Workplace: How to Overcome the Invisible Barriers to Quality, Productivity, and Innovation. San Francisco: Jossey-Bass.

Roberts, L. M. (2005). Changing faces: Professional image construction in diverse organizational settings. Academy of Management Review, 30: 685-711.

Rosenfeld, P. R., Giacalone, R. A., \& Riordan, C. A. (1995). Impression management in organizations: Theory, measurement, and practice. New York: Routledge.

Schlenker, B. R. (1980). Impression management: The self-concept, social identity, and interpersonal relations. Monterey, CA: Brooks/Cole.

Schneider, D. J. (1981). Tactical self-presentations: Toward a broader conception. In J. T. Tedeschi (Ed.), Impression management theory and social psychological research. New York: Academic Press.

Tett, R. P., \& Guterman, H. A. (2000). Situation trait relevance, trait expression, and cross-situational consistency: Testing a principle of trait activation. Journal of Research in Personality, 34:397-423.

Tedeschi, J. T., \& Riess, M. (1981). Identities, the phenomenal self, and laboratory research. In J.T. Tedeschi (Ed.), Impression management theory and social psychological research. New York: Academic Press.

Ting-Toomey, S. (1994). The challenge of facework: Cross-cultural and interpersonal issues. Albany: State University of New York Press.

Van Dyne, L., Cummings, L. L., \& McLean Parks, J. (1995). Extra-role behaviors: In pursuit of construct and definitional clarity. In B. M. Staw \& L. L. Cummings (Eds.), Research in Organizational Behavior. Greenwich, CT: JAI Press.

Van Dyne, L., \& LePine, J. A. (1998). Helping and voice extra-role behaviors: Evidence of construct and predictive validity. Academy of Management Journal, 41:108-119.

Van Dyne, L., Ang, S., \& Botero, I. C. (2003).Conceptualizing employee silence and employee voice as multidimensional constructs. Journal of Management Studies, 40(6): 1359-1392.

Vigoda, E. (2000). Organizational Politics, Job Attitudes, and Work Outcomes: Exploration and Implications for the Public Sector. Journal of Vocational Behavior, 57(3): 326-347.

Wayne, S. J., \& Ferris, G. R. (1990). Influence tactics, affect, and exchange quality in supervisor-subordinate interactions: A laboratory experiment and field study. Journal of Applied Psychology, 75: 487-499.

Wayne, S. J., \& Kacmar, M. K. (1991). The effects of impression management on the performance appraisal process. Organizational Behavior and Human Decision Processes, 48: 70-88. 